\title{
Intervention of National Economies to Health and Social Security: Antibiotic Policy as an Example of EU Solidarity with Migration Crisis or Social Pathology? (Note)
}

\begin{abstract}
M. Luliak (Milan Luliak)², M. Gulasova (Monika Gulasova)', J. Vallova (Jana Vallova) 1,3, R. Drabdury (Richard Bradbury)2, E. Grey (Eva Grey)', L. Libova (Lubica Libova) $)^{3}$, K. Prochazkova (Katarina Prochazkova)', P. Tomanek (Pavol Tomanek)', B. Hofbauerova (Blanka Hofbauerova)', J. Otrubova (Jana Otrubova)³) I. Hupkova (Inge Hupkova)', M. Sramkova (Maria Sramkova)', A. Topolska (Alexandra Topolska)', M. Jancovic (Mario Jancovic)', M. Katunska (Monika Katunska)1,3, H. Konosova (Helena Konosova)3) , S. Subramaniam (Selvaraj Subramaniam)2 V. Krcmery (Vladimir Krcmery) ${ }^{1}$
\end{abstract}

1 Dpt. of social work and psychology, PFF Institute, SEU, Bratislava,

Original Article SK and SEUC Health Post. Alexandria, Greece.

2 Public Health MSc (SEU) and Nutrition (BSc) Program, Kuala Lumpur, Malaysia.

${ }^{3}$ St. Lesley College, Nove Zamky, Slovakia.

${ }^{4}$ Dept of Immunology AKM Vienna, Austria.

\section{E-mail address:}

jana.otrubova@gmail.com

\section{Reprint address:}

Jana Otrubova

St. Lesley College and St. John Neumann Institute

Pribram

Czech Republic

Source: Clinical Social Work and Health Intervention Volume: 10

Issue: 4 Pages:

Cited references: 5

\section{Reviewers:}

Andrea Shahum

University of North Carolina at Chapel Hill School of Medicine, USA

Clauss Muss

I-GAP Zurich, Switzerland

\section{Keywords:}

Health Expenditure. Social pathology. 


\section{Publisher:}

International Society of Applied Preventive Medicine i-gap

CSWHI 2019; 10(4): 22 - 24; DOI: 10.22359/cswhi_10_4_06 @ 2019 Clinical Social Work and Health Intervention

\section{Abstract:}

Antibiotic consumption and policies are of great concern in Europe, mainly due to the growing ATB resistance and failure of ATB therapy. The aim of this note is to interprete the correlation between ATB consumption and resistance to ATB in 30 European (EU) European Economic Area (EEA) countries and search for the influence of state economies (eg. GDP, health expenditures etc.) to the ATB consumption. As result of solidarity and patients behavior.

\section{Introduction}

Increasing life expectancy worldwide is a positive economic and social phenomenon in high-income countries and is caused within last 50 years by decreasing mortality on both communicable and non-communicable diseases. Vaccines and antibiotics are major factor in decreasing mortality related to infectious diseases. However, increasing ATB consumption is reported on both hospital and nationwide levels.(1) Is ATB consumption the only driver of increased ATB resistance? Is high ATB-consumption on national level the major cause of ATB resistance or just a consequence of migration $(2,3)$ patients behavior, education and/ or social situation? $(3,4,5)$ The aim of this note is to interpret the correlation between ATB consumption and resistance to ATB in 30 European (EU) European Economic Area (EEA) countries and search for the influence of state economies (eg. GDP, health expenditures, migration, social pathology etc.) to the ATB consumption.

\section{Methods}

Data on ATB consumption and resistance were extrapolated from the ESAC study group (1) and data on GDP and health expenditures from $30 \mathrm{EU} / \mathrm{EEA}$ countries from the Global Burden of Diseases published in Eurostat 2018 and The Lancet 2019 were compared.

\section{Results and Discussion}

Consumption and resistance data from all $30 \mathrm{EU} / \mathrm{EEA}$ countries are to be found in tables 1 to 4 . Out-of-pocket spending and $\%$ GDP in particular countries were compared in 4 groups according to level of consumption and resistance.

Correlation was found in $60 \%$ of countries $(n=18)$, rest of the countries showed no correlation between consumption and resistance of ATB.

16 countries with high ATB-R (more than $20 \%$ mean ATB-R rate). 10 of them $(60 \%)$ has also high ATB consumption, mainly in Southern and Eastern Europe. Romania has also the highest resistance rates (45.9\%) followed by Slovakia, Greece, Bulgaria and Italy. However there were also countries in this group with low ATB-consumption and high resistance rates (Czech Republic, Hungary, Slovenia, Latvia, Lithuania, Estonia). Countries with low resistance rates, 8 of 14 countries, showed correlation with consumption and resistance, (mainly Scandinavian countries). In France, UK, Ireland and Belgium high consumption is not 
accompanied with high resistance rates. Explanation for this $60 \%$ consumption can be found in economy and financing of healthcare and discussed as a interesting phenomenon, which may explain this non-correlation. Countries with high resistance and consumption (group A) showed also high percentage of out of pocket spending on healthcare (28-32\% vs. 13-14\%). Countries with high ATB consumption but low resistance (group C) vice-versa showed significantly higher investments to healthcare $(8-9 \%$ of GDP vs. $6.0-6.1 \% \mathrm{p}=0.045)$ than in the countries with low consumption, but high ATB-R (group B). Differences are also in the spending on healthcare per capita, in group B it was on average 14001650 USD and in group C 5500-7500USD.

\section{Conclusions}

There is a partial correlation between ATB-resistance and consumption of antibiotics in EU/EEA. $60 \%$ of European countries, which have high ATB consumption, have also high ATB-resistance and countries with low consumption tend to have low resistance rates too. However, there is also correlation between out of pocket expenditure on healthcare and high consumption of ATB and investments to healthcare per capita also correlates to low ATB-R rate, possibly due to more resources spent to hospital hygiene, surveillance and preventive programs for ATB resistance due to charges of social pathology (migration, detention, patient behavior) and social policy, of particular state (4-5)

\section{Reference:}

1. MCDONNELL L, ARMSTRONG D, ASHWORTH M, DREGAN A, MALIK U, WHITE P (2017) National disparities in the relationship between antimicrobial resistance and antimicrobial consumption in Europe: an observational study in 29 countries. J Antimicrob Chemother. 2017 Nov 1;72(11):3199-3204. doi: 10.1093/jac/ dkx248. PubMed PMID: 28961862.

2. KALAVSKY E, KOZON V, JACKULIKOVA M, LISKOVA A, MURGOVA A, BELOVICOVA M, JANOVICOVA L, DURCOVA B, MATULNIKOVA L, NADDOUR A, TRILISINSKAYA I, SIMONEK T (2018) Refugees after long distance migrating and camping: Secondary Wound infection etiology and management. Original research. In: Clinical Social Work and Health Intervention. Vol. 9, Issue 4, 2018, pp. 68-71.

3. KALAVSKY E, MRAZOVA M, VANSAC P, PALUN M, OLAH M, BERESOVA A, DOKTOROV A, KOZON V, MARKS P (2018) Investment to joint academia programms in developing countries - one of effective social investment to prevent social pathology related to illegal migration. In: Clinical Social Work and Health Intervention. Vol. 9, Issue 4, 2018, pp. 72-74.

4. BELOVICOVA M, MURGOVAA, VANSAC P, POPOVICOVA M, BALAZOVA I, NEMCIKOVA M, MASTEROVA V, URBANOVA A, FABISKOVA K, BALAZIOVA A (2019) Hepatitis C Screening in selected social reintegration facillities in Eastern Slovakia. In: Clinical Social Work and Health Intervention. Vol. 10, Issue 2, 2019, pp. 25-31.

5. GLOBAL BURDEN OF DISEASE HEALTH FINANCING COLLABORATOR NETWORK (2019) Past, present, and future of global health financing: a review of development assistance, government, out-of-pocket, and other private spending on health for 195 countries, 1995-2050. The Lancet VOL 393, ISSUE 10187, P22332260, JUNE 01, 2019. 